\title{
A árvore das palavras, romance de consciência identitária
}

\author{
Aparecida de Fátima Bosco Benevenuto ${ }^{1}$
}

RESUMO: A ficção de Teolinda Gersão, A árvore das palavras, privilegia o elemento textual - espaço - com o intuito de mostrar, em relação aos sistemas literários dos países de língua portuguesa, como esse elemento é incorporado à narrativa numa transformação antropomórfica no desejo de figurar a consciência identitária da nação moçambicana.

ABSTRACT: The novel A árvore das palavras, by Teolinda Gersão, emphasizes the narrative element - space - to show the relations between the literary system of countries that speak portuguese language, incorporating anthropormorfic transformation, like a utopy to be conscious of Mozambican identity.

PALAVRAS-CHAVE: Espaço; ficção; identidade; nação; Moçambique KEYWORDS: Space; novels; identity; nation; Moçambique

Teolinda Gersão, autora do romance A árvore das palavras, publicado no Brasil em 2004, pela editora Planeta, nasceu em Coimbra em 1940. Estudou germanística e anglística nas Universidades de Coimbra, Tübingen e Berlim, foi professora na Faculdade de Letras de Lisboa e professora catedrática na Universidade Nova de Lisboa, onde lecionou Literatura Alemã e Literatura Comparada até 1995. Desde então, dedica-se, exclusivamente, à literatura² .

A autora residiu três anos na Alemanha, dois em São Paulo (inspiração para alguns textos de Os guarda-chuvas cintilantes, 1984); morou, também, em Moçambique, cuja capital, então Lourenço Marques, foi o espaço escolhido para o romance A árvore das palavras.

\footnotetext{
1 Mestranda em Estudos Comparados de Literaturas de Língua Portuguesa, FFLCHUSP. Pesquisa: Introspecção feminina: uma busca necessária (análise das obras Um dia são dias de Marta de Lima e Jogo de fiar de Patrícia Bins). E-mail: cidabene@ig.com.br.

2 www.telolinda-gersão.com.biografia.html.
} 
Recebeu, entre outros, o prêmio de romance e novela da Associação Portuguesa de Escritores pelo romance A casa da cabeça de cavalo (1995) e os prêmios de ficção do Pen Clube pelos livros O silêncio (1981) e O cavalo de sol (1989).

Em A árvore das palavras, Teolinda Gersão apresenta o espaço como figura personificada do desejo de consciência identitária em relação "aos sistemas literários nacionais dos países de língua portuguesa”. 3

O romance tem como fio condutor a história da protagonistanarradora (Gita) que, por meio de um olhar sensível e lúdico, convidanos a incursionar em suas lembranças. Na primeira parte da obra, Gita nos apresenta a casa branca, representada por sua família - brancos pobres, pertencentes a Moçambique - e a casa preta e o quintal, representados pela ama-de-leite Lóia. A terceira parte é composta pelas reflexões da já adolescente (Gita), apresentando ao leitor uma visão não mais idealizada do espaço moçambicano, mas, agora, um olhar politizado. Por um narrador em terceira pessoa, a história de Amélia, mãe de Gita, nos é apresentada na segunda parte da obra.

Moçambique aparece, nesta ficção, metonimicamente representada pela casa preta e pelo jardim/quintal, como espaços deflagradores e multiplicadores da formação da identidade da protagonista Gita. A narradora parece preferir os sons da casa preta e o cheiro do quintal, tão peculiares às populações de Moçambique, ao amargo constante de Amélia na casa branca.

Ao quintal chegava-se através da porta estreita da cozinha. E se é verdade que a cozinha era escura, nem por isso deixavam de ver os objectos, as panelas de alumínio e as gordas caçarolas, os púcaros e as tijelas de esmalte, o fogão esbranquiçado, de bocas de latão, a grande mesa com tampo de pedra onde havia sempre alguma louça esquecida. Mas sobre isso passava-se largo, sem realmente olhar, corria-se em direção ao quintal, como se se fosse sugado pela luz, cambaleava-se, transpondo a porta, porque se ficava cego por instantes, apenas o cheiro e o calor nos

3 ABDALA JR, Benjamin. De vôos e ilhas: literatura e comunitarismos. São Paulo: Ateliê, 2003, p.109. 
guiavam, nos primeiros passos - o cheiro da terra, a erva, a fruta demasiado madura - chegando até nós no vento morno, como um bafo de animal vivo (GERSÃO, 2004, p.9).

Pelo olhar infantil da narradora Gita, em duas fases: a infância e a adolescência, somos levados a conhecer duas nações em trânsito: a casa branca representada por Amélia - mãe portuguesa, costureira que se inspira na riqueza de suas freguesas - e a casa preta figurada por Lóia, a ama-de-leite negra. Deambula entre as duas nações o pai moçambicano Laureano, ao casar-se com Amélia.

A narrativa é estruturada a partir das vivências infantis da protagonista Gita (primeira parte) e, posteriormente, de suas reflexões na fase adulta (terceira parte). Sob os cuidados do pai Laureano e de Lóia, a casa preta e o quintal parecem proteger Gita das amarguras da casa branca.

Lóia dá um peito a uma e outro peito a outra, sentada na cozinha e no quintal. E assim eu ganho o mesmo cheiro de Orquídea e uma carne densa e flexivel, ao mesmo tempo cheia e sem gordura, coberta por uma pele macia como a seda (GERSÃO, 2004, p.16).

As descobertas de Gita acontecem distantes da casa branca, representada pela mãe, Amélia, mulher que saiu de Lisboa em busca de uma vida compatível com seus sonhos e que levada por um anúncio de jornal, debruça-se sobre Moçambique; todavia, torna-se amarga por pertencer à classe branca pobre dessa terra e acaba por viver sem criar raízes com a família. "É preciso cuidado, dizia Amélia. Estar atento. Tudo parece bem à superfície, mas a cidade está podre e cheia de contágios. Ela foi construída sobre pântanos” (2004, p.10).

Em constante diálogo com o pai Laureano em seu espaço de lembrança: o quintal, para Gita, é reconstruído a partir de seus pormenores, como se a vida brotasse dali; enquanto a mãe, Amélia, aprisiona-se na casa branca para não ser contaminada pela cultura africana. 
Em baixo - enquanto ele [Laureano] se sentava na varanda - o quintal crescia como uma coisa selvagem. Brotava um grão de mapira atirado ao acaso ou deitado aos pássaros, brotava um pé clandestino de feijão manteiga ao lado dos malmequeres, brotavam silvas e urtigas e ervas sem nome no meio da chuvade-ouro e da bauínea - qualquer semente levada pelo vento se multiplicava em folhas verdes, lambidas pelas chuvas do verão. $\mathrm{E}$ Amélia diria, franzindo a testa: O jardim tornou-se um matagal. E fecharia com força a janela. (2004, p.10).

Teolinda Gersão destaca-se por uma escrita que se organiza em torno de flashes de memória e da alternância de foco narrativo, o que resulta na construção de momentos delicados ao longo do romance, por meio do olhar afetivo/carinhoso lançado pelas personagens em relação ao ambiente que permeia esta narrativa e, portanto, a vida dessas mesmas personagens junto à nação moçambicana, junto ao jardimquintal da menina a crescer ao "cheiro da terra, da erva, da fruta demasiado madura”. O parágrafo a seguir nos permite um percurso sinestésico característico neste romance da autora:

Todas as coisas, no quintal, dançavam, as folhas, a terra, as manchas de sol, os ramos, as árvores, as sombras. Dançavam e não tinham limite, nada tinha limite, nem mesmo o corpo, que crescia em todas as direções e era grande como o mundo. $\mathrm{O}$ corpo era a árvore e o corpo era o vento. Tocava-se no céu levantando apenas um pouco a cabeça, balançava-se no vento dançando, nessa altura a vida era dançada, só de pôr um pé diante do outro o corpo se acendia em festa: tudo estava nele e era ele, os gritos altos dos pássaros, o bafo quente do Verão africano, a grande noite povoada de estrelas. Mas o infinito não tinha sobressalto, nem sequer surpresa, era uma idéia simples, apenas a certeza de que se podia crescer até o céu (2004, p.10).

O romance ainda propõe uma relação metonímica entre as duas nações: primeiro, na casa preta, figuração de África,

(...) não havia medo dos mosquitos, nem se receava, a bem dizer, coisa nenhuma. Na casa Preta as coisas cantavam e dançavam. As galinhas saíam do galinheiro e pisavam a roupa caída do estendal, cagando alegremente sobre ela, Lóia gritava enxotandoas mas desatava a rir ajoelhada na terra, esfregava outra vez a roupa com um quadrado de sabão e regava-a com o regador cheio de água. Parecia divertir-se a fazer as coisas, porque ria sempre nunca prendia realmente as galinhas, que tornavam a cagar na 
roupa, que ela regava outra vez - a água saía em chuva pela mão do regador que balançava na mão dela. E pelo caminho entre a torneira e a roupa, ela ia ressuscitando as flores (2004, p.11).

Em seguida, na casa branca, figuração de Portugal,

(...) quando alguém adoecia ela [Amélia] pensava sempre em febres antigas, que periodicamente voltavam e deixavam as pessoas olheirentas e débeis, como sugadas por espíritos malignos. O pântano, ou a memória do pântano, que nunca conhecera porque tinha sido extinto há quase um século, parecia assediá-la ainda, em visões de pesadelo. Como se estivesse ali muito perto a água apodrecida das lânguas. $\mathrm{E}$ acompanhava ela mesma o guarda sanitário e o sipaio, que vinham de longe em longe, de braçadeira amarela, vasculhar o quintal, pulverizando os cantos e os muros com um produto malcheiroso que devia exterminar ou afugentar os mosquitos (2004, p.11).

No embate entre os dois espaços acima, torna-se evidente a diferença cultural entre as duas nações e o papel do colonizador em terra ocupada. À época de colônia, Portugal desdenha-se da infraestrutura, da cultura e da paisagem moçambicanas, pois o foco político concentrava-se na exploração das riquezas da região e na localização favorável à rota marítima comercial.

A irmandade existente entre Gita e Orquídea (filha de Lóia), na infância, parece metaforizar um possivel diálogo entre as duas nações:

O dia inteiro eu era sua. Orquíiiiideaaa, grito abraçando-a, debaixo do jacarandá. Ela deixa-se abraçar até ficar sem fôlego, agarra punhados de terra com as mãos, atira-os com força. Lutamos, tapando os olhos, sacudimos a terra da cabeça (2004, p. 17).

mas a morte precoce de Lóia distancia-as, apesar das visitas de Gita e Laureano e a ajuda financeira à família de Lóia.

$\mathrm{Na}$ terceira parte do livro, ao re(conhecer) sua posição no espaço moçambicano, a adolescente Gita desperta para a política da terra que a acolhera; aos poucos, encara a vida que se apresenta a sua frente. Enquanto Amélia permanece 
no quarto da costura, curvada sobre a máquina que tem escrito no dorso: Pf a ff, em grandes letras separadas. Ouve-se no corredor o seu zumbido enervante e monótono, interrompido de onde em onde pelo estalar das linhas, e uma vez por outra pelo som agudo, metálico, da tesoura caindo (2004, p.19),

ou seja, na interminável tarefa de tecer a própria história, já que neste momento, a vida de Amélia está focada em África, outrora em Lisboa e, perseguindo seu sonho de grandeza, em outro anúncio de jornal, em Sidney, na Austrália.

Um narrador em terceira pessoa assume a segunda parte do romance para nos contar a história de Amélia, em terra portuguesa: abandonada pelo namorado Quim, órfã e morando com a madrinha que a desdenha, Amélia sente-se excluída de sua terra. Em um anúncio de jornal, "moçambicano procura moça até 25 anos para casamento", depara-se com a possibilidade de uma outra vida, do outro lado do Atlântico. No entanto, pertencente à parte pobre de Moçambique, rejeita o contato com a identidade africana.

Procura distanciar-se ao máximo desse povo, tranca-se dentro de casa para não ser contaminada pela diversidade cultural que a cerca, além de negar a identidade do marido e da filha. Quando sai às ruas, aos domingos, às escondidas de Laureano e Gita, sente-se à margem do que tanto almejava. "Esse lado não lhe pertencia. Ela era apenas visitante, não lhe cabia mais do que um rápido olhar, quase furtivo" (2004, p.21).

Talvez movida pelo "feitiço" da ainda menina Gita, "vai-te embora e não voltes. Não voltes nunca mais” (2004, p.76), Amélia percebe, na forma de um outro anúncio, seu destino ancorado mais adiante do Índico, em Sidney, na Austrália.

A protagonista assume, novamente, o foco narrativo na terceira parte do romance para evidenciar sua integração com o ambiente africano durante seu crescimento. Por meio do recurso sinestésico, a natureza parece movimentar-se para protegê-la e acolhê-la. 
O primeiro amante era o sol, andando em volta do corpo deitado, lambendo-o com a sua língua de lume, batendo-lhe ao de leve com a sua cauda, farejando-o com o seu focinho de luz - via-se isso através das pálpebras, sem abrir os olhos, enquanto o corpo amolecia e se sentia mais forte o cheiro do vento - e agora o sol começava a apoderar-se de todo o corpo, avançava sobre ele com pés cautelosos, como um animal bravio e a gente entregava-se, rendida, e o sol entrava pela pele, pelos ouvidos, pelas narinas, pela boca, e havia finalmente o momento em que se abandonava de todo a resistência e se afastavam também as pernas e se recebia o sol no meio do corpo - o sol, sim era o primeiro amante (2004, p.133).

Embora se sentisse parte do ambiente natural africano, Gita entendia que "a vida era uma árvore crescendo e, lá onde os ramos se apartavam, havia um tempo que chegava ao fim” (2004, p.135).

Sensibilizada desde pequena pelo pai para as questões políticas, a jovem Gita se depara com uma África paradoxal,

Era isso o que lhes importava, esse espetáculo era a missa. Apesar do ar compuncto, concentrado e quase humilde que punham na altura da confissão e comunhão. Mas era tudo impostura e fingimento, iam lá não para se sentirem iguais aos outros, mas para afirmarem a sua posição de privilégio, e saíam de lá para continuarem a viver da mesma forma, para que haviam de mudar alguma coisa se tudo estava tão bem organizado assim, eles reinando e os outros servindo, agora e para sempre amém (2004, p.161).

Mas Gita não se intimida, une-se a um grupo de amigos, no início da guerra colonial, para lutarem por uma nação independente, pois tinha consciência de que tanto ela quanto Moçambique necessitavam dessa liberdade, mesmo sabendo das dificuldades que ela enfrentaria em Lisboa (na casa de parentes) para continuar seus estudos e das dificuldades de Moçambique para re(estruturar)-se como nação independente.

Representado por Gita, o discurso ideológico de A árvore das palavras internaliza uma visão utópica ${ }^{4}$ de ascensão do povo moçambicano,

4 Segundo Ernest Bloch, entende-se utopia "como um topos da atividade humana voltada para o futuro, um lugar da consciência antecipadora e a força ativa dos 
Ela crescia nos sonhos, digo a Roberto enquanto pintamos o cartaz. A árvore das palavras. Para contornar o seu tronco seriam precisas nove luas. E cada folha era extensa como um vôo de pássaro. Mas de certeza que não só nos meus sonhos: Crescia também nos de toda a gente (2004, p. 170).

Ao apreender o que era inaudível dentro do espaço moçambicano àquela época, A árvore das palavras - árvore com o significado de "vegetal de grande porte, lenhoso", "mastro de embarcação", "eixo"5 e palavra - "som articulado, com uma significação", "termo", "vocábulo", "declaração", "promessa verbal"6 - ecoa o desejo utópico (simbolizado pela árvore como eixo, embarcação e pela palavra como som articulado, com uma significação), metaforizando a nação em formação com suas múltiplas identidades.

\section{Referências bibliográficas}

ABDALA, JR., Benjamin. Literatura - História e Política. São Paulo: Ática, 1989. . De vôos e ilhas: literatura e comunitarismos. São Paulo: Ateliê, 2003.

BHABHA, Homi K. O local da cultura. Trad, Myiriam Ávila, Eliana Lourenço de Lima Reis e Gláucia Renate Gonçalves. Belo Horizonte: Editora UFMG, 2005.

CÂNDIDO, Antônio. O discurso e a cidade. São Paulo: Duas cidades, 1993.

DIMAS, Antônio. Espaço e romance. São Paulo: Ática, 1987.

GERSÃO, Teolinda. A árvore das palavras. São Paulo: Planeta, 2004.

HUTCHEON, Linda. Poética do pós-modernismo: história, teoria, ficção. Trad. Ricardo Cruz. Rio de Janeiro: Imago, 1991.

LINS, Osman. Lima Barreto e o espaço romanesco. São Paulo: Ática, 1976.

LUCKÁCS, Georg. A teoria do romance. São Paulo: Editora 34, 1985.

MÜNSTER, Arno. Ernest Bloch - Filosofia da práxis e utopia concreta. São Paulo: Unesp, 1991.

NITRINI, Sandra. Literatura comparada: História, teoria e crítica. 2.ed. São Paulo: Editora da Universidade de São Paulo, 2000.

NUNES, Benedito. O tempo na narrativa. São Paulo: Ática, 1988.

POUILLON, J. O tempo no romance. Trad. H. de Lima Dantas. São Paulo: Cultrix, 1974.

sonhos futuros" (MÜNSTER, 1991).

${ }^{5}$ Aurélio eletrônico. 
RODRIGUES, Inara de Oliveira. O espaço do incomunicável em a Árvore das palavras, de Teolinda Gersão, disponível em < www. Revistaseletronicas.pucrs.br > último acesso em 06 de nov. de 2007. 